\title{
セルロース類の ESCA
}

東京農工大学農学部 佐渡 篤, 高島藤順

\section{ESCA of Some Celluloses}

\author{
Atsushi Sawatari and Tohjun Takashima \\ Faculty of Agriculture, Tokyo University of Agriculture and Technology \\ Saiwaicho 3-5-8, Fuchu-shi, Tokyo
}

ESCA of celluloses with various crystallinity was discussed. The ionization potential $W_{1}(\mathrm{eV})$ of $\mathrm{C}_{1}$ s electron varied with the crystalinity index $\mathrm{Cr}(\%)$ of the cellulose. The linear relation was observed between $\mathrm{W}_{1}$ and $\mathrm{Cr}$. Namely, the following relation was obtained.

$\mathrm{W}_{1}=-0.03049 \mathrm{Cr}+284.6\left(\mathrm{r}=0.643^{* *}, \mathrm{n}=17\right)$

Possible interpretation of the shift of the $\mathrm{C}_{1}$ s signals are as follows:

(1) The electron of hydrogen atom attracted to oxygen of proton donner in celluluose molecule.

(2) The contaminant carbon or charges on cellulose surface may influenced on $\mathrm{C}_{1} \mathrm{~s}$ signals. At present, no definite conclusion was obtained concerning above-mentioned interpretations.

\section{要旨}

結晶化度の異なるセルロースの ESCA スペクトル を水素結合状態に着目して検討した。その結果，結晶 化指数の大きなセルロースについて $\mathrm{C}_{1 \mathrm{~s} P e a k}$ を観測 すると，結晶化指数の小さい試料に比べてイオン化ポ テンシャルの小さいところに Peak が現れた。C $\mathrm{C}_{1 \mathrm{~s}}$ を 示すイオン化ポテンシャル $W_{1}(\mathrm{eV})$ と結晶化指数 $\operatorname{Cr}(\%)$ の間には直線関係が認められ，非晶から結晶 に変化するにつれて約 $3 \mathrm{eV}$ の減少が認められた。即 ち，次式によって示される。

$\mathrm{W}_{1}=-0.03049 \mathrm{Cr}+284.6 \quad\left(r=0.643^{* *}, n=17\right)$

この結果は，観測された C 1 sPeak がセルロース分 子のそれである場合は, 水素の電子の供与体酸素の側 への移動の効果によって説明されるものと思われる。

また，観測結果がセルロース表面の污染物の炭素な どの影響をかなり受けている場合は，セルロースの $\mathrm{C}_{1 \mathrm{sPeak}}$ を示すイオン化ポテンシャルは約 $283 \mathrm{eV}$ で あり，通常の合成高分子等に比べて $2 \sim 3 \mathrm{eV}$ 低い值 であると言える。観測された事実が上述のいずれによ っているのかは目下帰着しがたい。

\section{1. 緒 言}

筆者らは 2 年程前からと ESCA いら分光法に着目 していたが, 今回結晶化指数の異なるセルロースの ESCA スペクトルについて実験結果について報告す る。

先ず ESCA とは何かという点に若干触れることと する。 ESCA は Electron Spectroscopy for Chemical Analysis (化学的な解析のための電子分光学) の
略号であり，その有力な開発者である K. Siegbahn によって命名されだ、この電子分光学の内容は，ア ルカリ金属以外の元素 (目下水素は除外) であっても 充分な感度と分解能をもって光電効果分再現性よく観 測できるようになったこと，ならびにこの分光法によ り物理的・化学的に重要なデータが得られるようにな ったことの 2 点である。

光電効果とは，アルカリ金属などに光が入射すると き，その光の波長加その金属元素によって決まる一定 の值より短い場合に，その金属から電子が飛び出して くる現象のこといらが，この現象は今世紀初頭には充 分確かめられていだ。この現象はＡ. Einstein の考 えによって次のように説明される2゙。「金属中の電子の 一つと衝突する光量子はそのエネルギー h⿻ の総てを 金属中の電子に与光るこのエネルギーを受けとった 電子は金属から飛び出す。しかしがらこのとさその 電子は金属表面から飛び出す前に，光量子からもらっ たエネルギーの一部を金属から出るために必要な仕事 Wに費やす。」この考光によって飛び出して来る電子 のエネルギー $\frac{1}{2} \mathrm{~m} v^{2}$ を表わすと次の(1)式を得る。

$$
\frac{1}{2} \mathrm{~m} v^{2}=\mathrm{h} \nu-W
$$

ここに h山は光量子のエネルギー，Wは電子を金属 から解放するために必要な最低のエネルギーである。

今，後のために(1)式を書き換えて(2)式を得る。

$$
W=\mathrm{h} \nu-\frac{1}{2} \mathrm{~m} v^{2}
$$

つぎに，(2)式のWの物理的意味を考えて見る。この W以上の大きさをもつ光量子が入射しないと電子は飛 
Table 1 Electron Binding Energies in eV

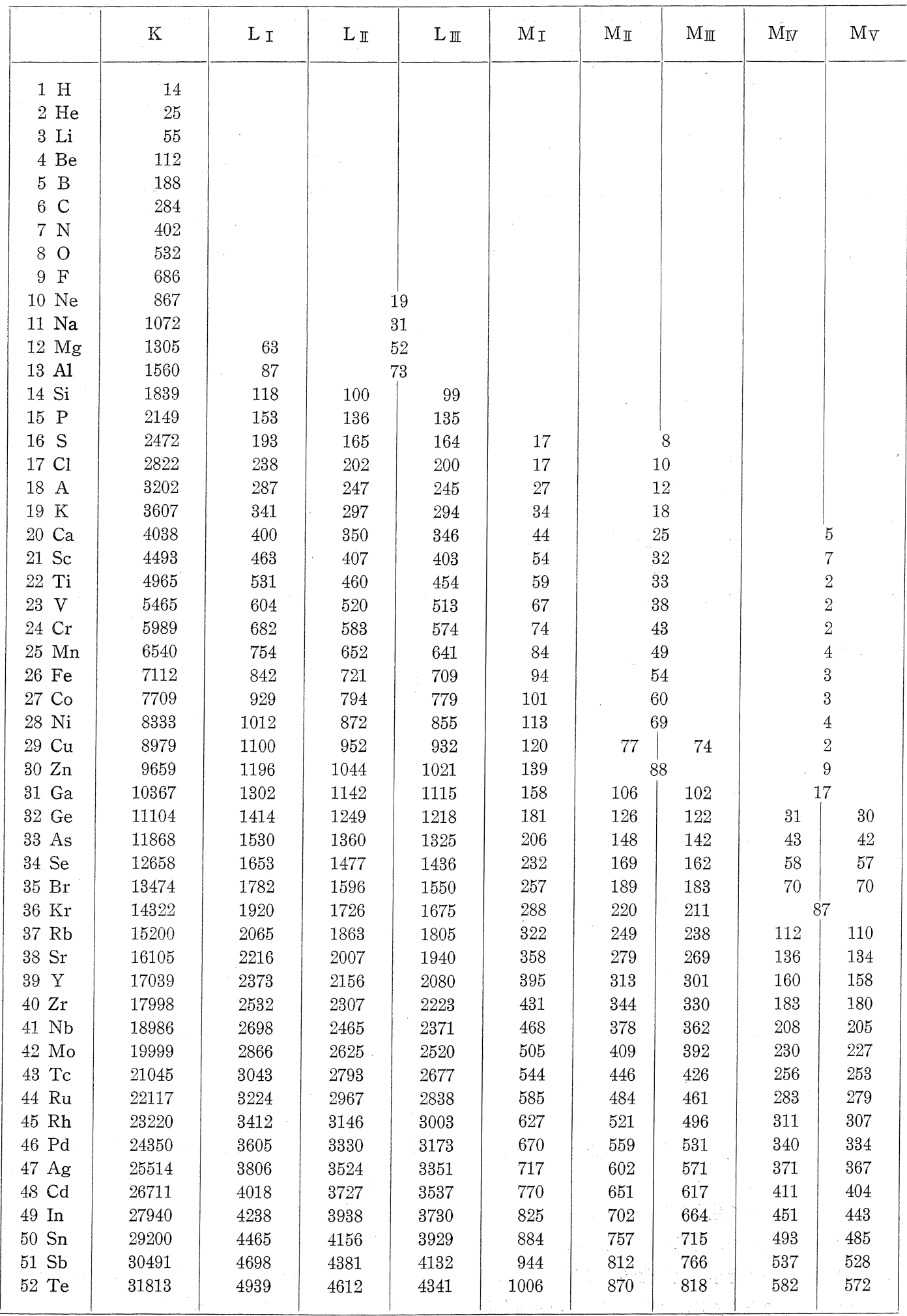


び出せない，それはその電子が原子中に束縛されてい るからである。したがってWは基本的にその電子が束 縛されている強さを意味している。また電子が 1 個飛 び出すとき，その原子は十にイオン化するのでWはイ オン化ポテンシャルの值に等しい。

今, 一定のエネルギー $h \nu_{0}$ をもつ光量子をある原 子にあてて飛び出して来る電子の速度 $v_{1}$ を測定すれ ば，その運動エネルギー $\frac{1}{2} \mathrm{~m} v_{1}^{2}$ を求めることができ るので，(2)式からその差 $\mathrm{h} v_{0}-\frac{1}{2} \mathrm{~m} v_{1}{ }^{2}$ によってその 原子のイオン化ポテンシャル $\mathrm{W}_{1}$ を求めることができ る。実際的には，光量子としては自然幅の小さな $\mathrm{X}$ 線 や He の共鳴線が用いられ，飛び出して来た電子の運 動エネルギーは電場型や磁場型のアナライザーによっ 求める。

K. Siegbahn および C. Nordling ら，D.W. Turner らそして F. I. Vilesov らは，この光電効果は アルカリ金属以外の元素に执いても必ず観測される筈 であると考光，多くの実験の後に，諸種の元素から光 電効果を再現性よく観測することに成功した。その鍵 は主として，アナライザー中の地磁気の影響の除去, 高真空技術の向上持よび電子計測技術の向上にあった が，これらの点に関しては他の優れた総説があるので それらにゆずる1),3),40

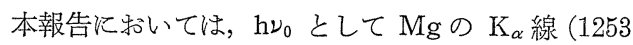
$\mathrm{eV})$ と $\mathrm{Al}$ の $\mathrm{K}_{\alpha}$ 線 $(1487 \mathrm{eV})$ を用いたので各々の X線を用いた場合のイオン化ポテンシャル $\mathrm{W}_{1}$ は，(2) 式によって次の(3), (4)式のように求められる。

$$
\begin{aligned}
& \operatorname{MgK}_{\alpha}: W_{1}=1253-\frac{1}{2} \mathrm{~m} v_{1}^{2}(\mathrm{eV}) \\
& \mathrm{AlK}_{\alpha}: W_{1}=1487-\frac{1}{2} \mathrm{~m} v_{1}^{2}(\mathrm{eV})
\end{aligned}
$$

Siegbahn らはこの $\mathrm{W}_{1}$ をその電子が核の正電荷に より結合されているためのエネルギーと考光 Binding Energy と名付けた ${ }^{5)}$ 。各元素の各電子について彼等 が決定した值 ${ }^{1)}$, 4)を表 1 に示した。

従来, 各元素のイオン化ポテンシャルの值は Landolt-Börnsteinの表などに集成されているが，いずれ もその元素が原子状態となっている場合の結果であっ て分子状態ではない。ところが ESCA の測定による 場合は $10^{-6} \sim 10^{-10}$ Torr 中の固体試料にX線などをあ て放出電子の速度を観測するといら方法をとるので， 固体状態に和けるその原子の $W_{1}$ を求めることができ る。ESCA は固体中の電子の各エネルギー・レベルを 実験的に求め得るので, 諸種の理論值と比較検討がで き，物性物理・量子化学・生物化学などの分野に大き な威力をるつものと言える。さらに応用面の特徽とし
て，ESCA スペクトルの Peak 位置が元素により異 なるために分析（主として定性，定量も可能）に利用 できること，化学シフトの観測によって化学結合によ るエネルギー・レベルの変化を求めることがでさるこ と，そして表面 ( $100 \AA)$ の情報が得られることなど が揭げられる。いずれにせよこれらの特徴は ESCA がイオン化ポテンシャルを充分な分解能で再現性よく 求めることができることに基因している。

また，今後，紙パルプ関係に特いても諸シートやフ イルムなどの表面状態解析や表面物質の迅速分析など に用いられる可能性も充分あると思われる。

筆者らは吒解度の異なるパルプシートの水素結合に 着目する立場から，各シートの水素結合状態を検索す るために諸種の分光学的性質を観測しその意味を検討 して来た。低分子化合物に物いては，水素結合のエネ ルギーはプロトン受容体のイオン化ポテンシャルと深 く関係すること吕が知られている。

水素結合状態が ESCA スペクトルに現れる例とし て，酢酸蒸気と固体状酢酸の $\mathrm{O}_{1 \mathrm{~S}}$ スペクトルが異な

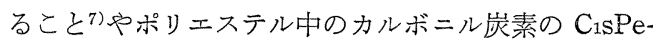
ak が Doublet になって現れることなどがある。今 回，筆者らは強い水素結合を示す $\mathrm{NaHF}_{2}$ についての スペクトル $\left(\mathrm{F}_{1} \mathrm{~S}\right)$ と $\mathrm{NaF}$ のそれを比較検討した。

Fig. 1 に示すように, $\mathrm{NaHF}_{2}$ の $\mathrm{F}_{1 \mathrm{~S}}$ は $\mathrm{NaF}$ の それより約 $0.5 \mathrm{eV}$ ほどイオン化ポテンシャルが小さ くなっていることが認められた。また同様のことがジ メチルグリオキシムの $\mathrm{O}_{1 \mathrm{~S}}$ スペクトルからも認めら れた。

したがって，吒解度の異なったパルプから得られた シートについて ESCA による検索を和こなら方法が 考えられる。

しかしながら，従来筆者らが吒解度の異なるパルプ シートの広幅法 NMR を観測した結果では，二次モ ーメント $<\Delta \mathrm{H}^{2}>$ の值は Fig. 2 飞示すように吒解の 進行につれて極く僅かながら減少する傾向を示した。

この結果は Pitman らす) がセルロースの Accessibility の增加は二次モーメント $<\Delta \mathrm{H}^{2}>$ の減少をも たらすと報告していることと一致している。

NMR から得られる $<\Delta \mathrm{H}^{2}>$ は Accessibility に 依存するが，ESCA から得られる W1 も Accessibility に依るか否かを先ず検討する必要が生じる。

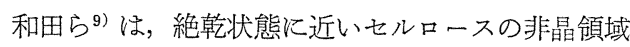
の $\mathrm{OH}$ 基は水素結合して拉らず，セロファンの場合 含水率約 $5(\%)$ で水との水素結合が飽和に達するとの 見解を述べ，そのことを含水率を変化させたときのセ ロファンの比重のデータから裏付けた。 
一般に ESCA の測定は試料を $10^{-7}$ Torr 程度の真 空中に和いておこなうので，少くともセルロースの非 晶領域の $\mathrm{OH}$ は相互に水素結合していない数が多い と考光られる。したがって, 非晶領域量の多いセルロ 一スでは水素結合をしていない $\mathrm{OH}$ 基の数が多いため に，イオン化ポテンシャル $\mathrm{W}_{1}$ の変化として ESCA スペクトルに現れるのではないかと考えた。以上の観 点に立って Accessibility の異なる諸セルロースの

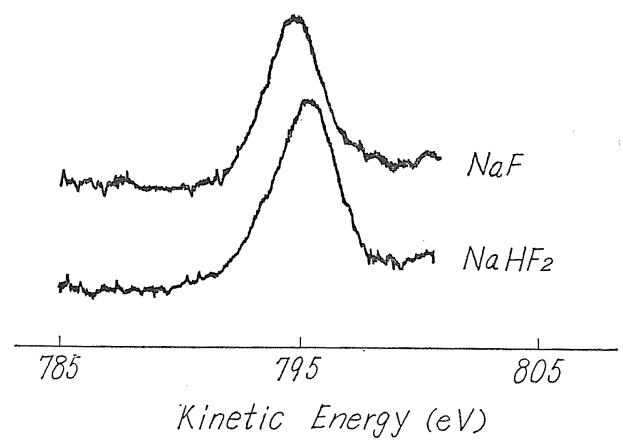

Fig. $1 \mathrm{~F}_{1 \mathrm{~S}}$ Spectra $\left(\mathrm{AlK}_{\alpha}\right)$
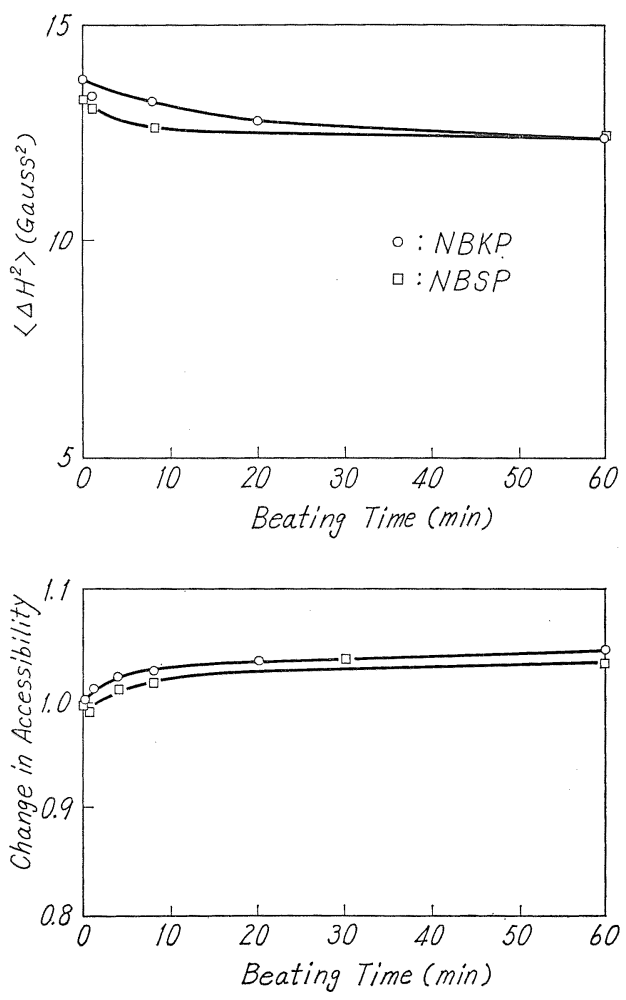

Fig. 2 Second Moment $<\Delta \mathrm{H}^{2}>$ and Change in Accessibility vs Beating Time NMR measurement were carried out at absolutely dried state.
ESCAについて検討することとした。

\section{2. 実験}

セルロース試料は結晶化指数の小さいものから酢酸 セルロース䲓化物， $17.5(\%)$ 扣よび $13.0(\%) \mathrm{KOH}$ 処 理 NBKP，市販セロファン，無添加セロファン，レ 一ヨン, NBSP 特よび NBKP, Avicell, 綿リンタ 一, ラミー, Valonia Macrophysa, Valonia Ventricosa を用いた。レーヨンは熱水処理後水洗してシ 一ト状とし，他の繊維はアルコール・ベンゾール抽出 後シート状とし, 市販セロファンは水抽出後風乾し実 験に供した。測定は英国 AEI 社製のES-100ならびに 国際電気株式会社製 $\mathrm{V} \mathrm{K}-5 \mathrm{~B}$ を用い真空度は $(1 \pm 0.3)$ $\times 10^{-7}$ Torr とし，基準 Peak としては $\mathrm{Au}$ の $\mathrm{N}_{7}$ の運動エネルギーを $1403 \mathrm{eV}$ に選んだ。各セルロー ス試料の結晶化指数の算出はX 線分析図から Norimoto $^{10)}$ らの採用した方法によって执こなった。X線 回析図は日本電子 JDX-7S 型 X線回析測定装置によ って求めた。

\section{3. 結果}

綿リンターの ESCA スペクトル (Wide Scanning)を Fig. 3飞示す。これから $\mathrm{O}_{1} \mathrm{~s}$ と $\mathrm{C}_{1 \mathrm{~s}}$ の Peak が圧倒的に感度良く現れることがわかる。セルロース 中の水素結合は $\mathrm{O} \cdots \cdot \cdot \mathrm{H}$ 型であるのでHについての 観測ができない現在，Oのスペクトルを観測し検討す る方法が考光られる。Fig. 4 に綿リンターの O IS と 無添加セロファンの $\mathrm{O}_{1 \mathrm{~s}}$ を高分解能で記録したスペク トルを示す。Fig. 4 から O $1 \mathrm{~s}$ には予期した差異が認 められなかったが, この結果はセルロース中の $\mathrm{O}_{1 \mathrm{~S}} に$ よるものなのか，ポリエチレンの場合のように吸着酸 素による11)ものかは判定し難い。したがって，目下の ところ O $\mathrm{I}_{\mathrm{s}}$ Peak によってセルロースの水素結合のエ ネルギー状態を検索することは無理があると判断した。

次に C $\mathrm{C}_{\mathrm{s} P \text { Peak }}$ を比較した場合を Fig. 5 に示す。 この場合は明らかに結晶化指数の大きいもの程イオン 化ポテンシャルが小さくなっている。また，17.5（\%) ならびに $13.0(\%) \mathrm{KOH}$ 処理 $\mathrm{NBKP}$ シートの $\mathrm{C}_{1 \mathrm{~S}}$ Peak を Fig. 6 に示す。 NBKP の C.S.F.703cc, $417 \mathrm{cc}, 262 \mathrm{cc}$ であるパルプから得たシートの $\mathrm{C}_{1 \mathrm{~s}}$ Peak を. Fig. 7 に, NBSP の C.S.F. 727 cc, $572 \mathrm{cc}$ であるパルプより得たシートの $\mathrm{C}_{1 \mathrm{~S}}$ Peak を. Fig. 8 に示す。

Fig. 7 から吒解の進行につれてイオン化ポテンシャ ルが僅かながら大きくなる傾向のあるごとがわかるが， Fig. 8 からはこの変化は認められない。測定した全試 
料の結晶化指数を横軸にとり, 縦軸に $\mathrm{C}_{1 \mathrm{~S}}$ イオン化 ポテンシャルをプロットして Fig. 9 亿示す。

Fig. 9 より, 結晶化指数の増加により $\mathrm{C}_{1 \mathrm{~S}}$ のイオン 化ポテンシャルが減少する傾向があり，両者の間には ばらつをながらも直線関係が認められ, 非晶から結晶 飞変化するにつれて約 $3 \mathrm{eV}$ 隇少することがわかる。
4. 考察

Fig. 9 は観測された事実をプロットしたものである が，この $\mathrm{C}_{1 \mathrm{~s}}$ Peak がセルロースの孷素からの信号で あるならば，結晶化指数の大きいセルロースの $\mathrm{C}_{1} \mathrm{~s}$ Peak はイオン化ポテンシャルの小さいところに現わ れると見なすことができる。このことは水素のもつ電

\section{5}

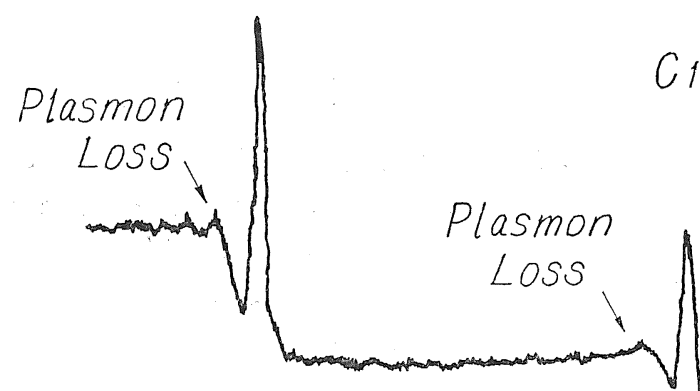

C1S

$O_{2 S} C_{2 P}$

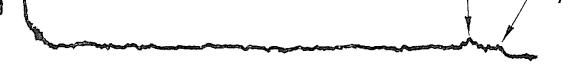

$\frac{1}{900} \quad \frac{1}{1000} \quad \frac{1}{1300}$

Fig. 3 Wide Scanning Spectrum of Cellulose (Cotton Linter) $\left(\mathrm{AlK}_{\alpha}\right)$

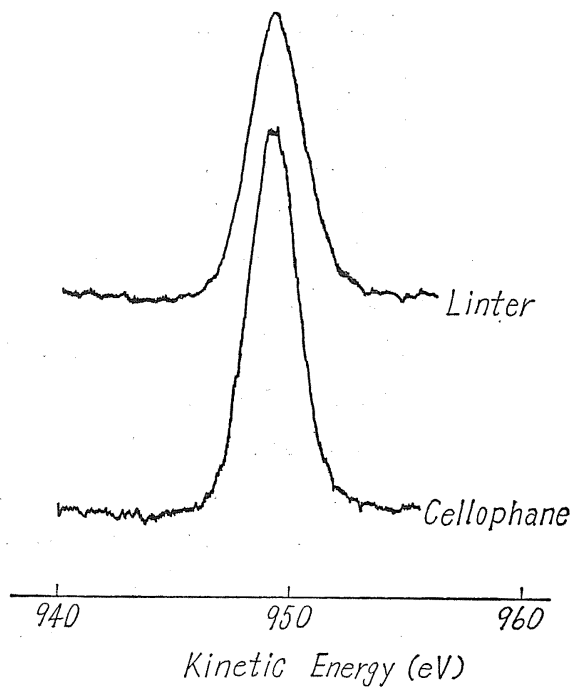

Fig. $4 \mathrm{O}_{1 \mathrm{~s}}$ Spectra $\left(\mathrm{AlK}_{\alpha}\right)$
子の酸素側への移動の効果 ${ }^{12)}$ 落酸素汇結合している炭 素によって観測されたためと考兄られる。

Fig. 9 亿执いて観測された事実がセルロースの $\mathrm{C}_{1 \mathrm{~s}}$ のみならず吸着された真空ポンプ油なぞの污染物の

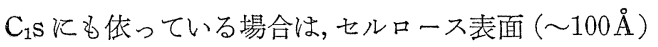
飞対する油分子の吸着量の相違が現われているものと 考光られる。しかしながら，仮り飞油分子の $\mathrm{C}_{1} \mathrm{~S}$ を 多く観測している場合でも, 油の $\mathrm{C}_{1} \mathrm{~s}$ のイオン化ポ テシャルは $286 \mathrm{eV}$ 前後であるので，セルロース自体 の $\mathrm{C}_{1} \mathrm{~s}$ は $283 \mathrm{eV}$ といら若干低い值をもつことが確 認されたことになる。

目下のところFig. 9 の事実がセルロ一ス中の水素の 電子移動の効果火よるのか表面污染物あるいは表面電 荷の影響などによるのかは判定し難い。

\section{謝 辞}

本研究を扮こならにあたり，種々の討論に招いて大 变拈世話になった国際電気株式会社星野清氏, 稲舟健 治氏, 吉松 進氏, Valonia の入手に御尽力戴いた東 京農工大学日高敏隆教授ならびそ種々御示唆戴いた東 


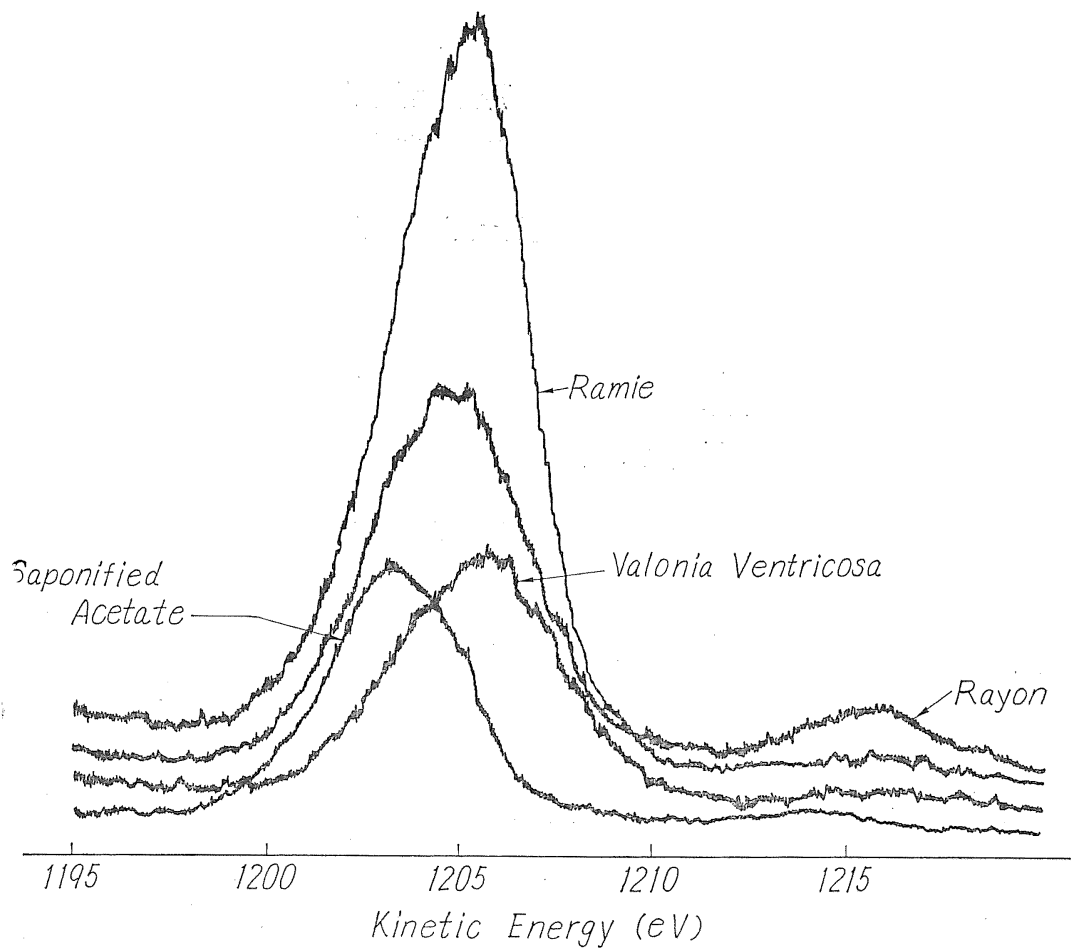

Fig. 5

$\mathrm{C}_{1} \mathrm{~s}$ Spectra of various Celluloses $\left(\mathrm{A} 1 K_{\alpha}\right)$
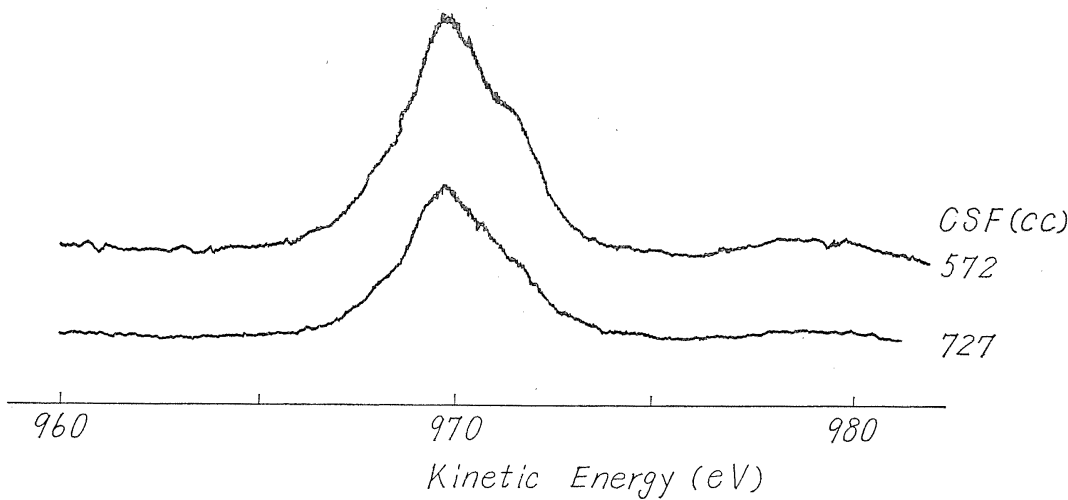

Fig. 6

$\mathrm{C}_{1} \mathrm{~S}$ Spectra of Hand Sheet from Pulps Treated with $\left(\mathrm{MgK}_{a}\right)$

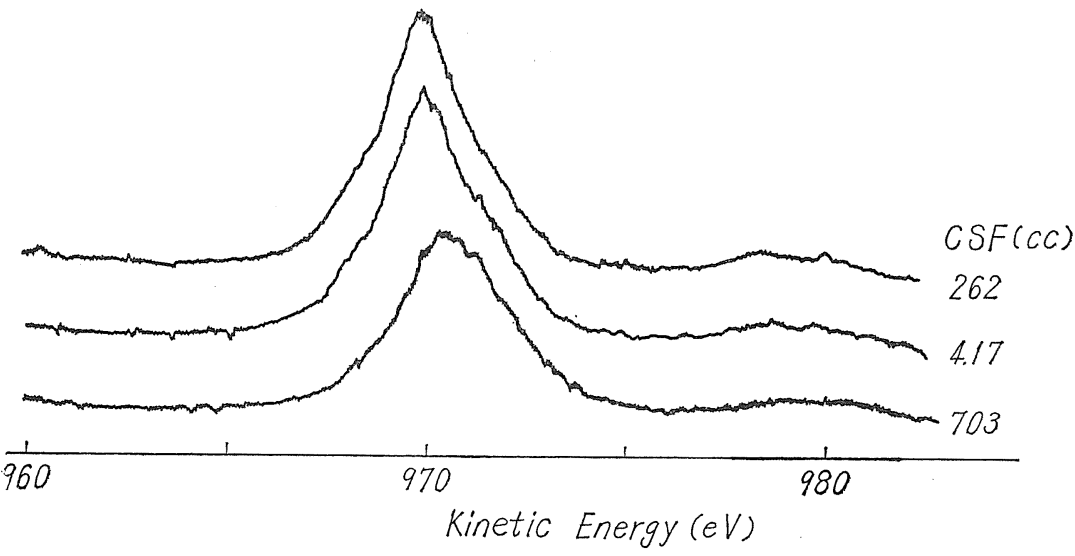

Fig. 7

$\mathrm{C}_{1 \mathrm{~S}}$ Spectra of Sheets from Softwood Sulphate Sulp $\left(\mathrm{MgK}_{\alpha}\right)$ 


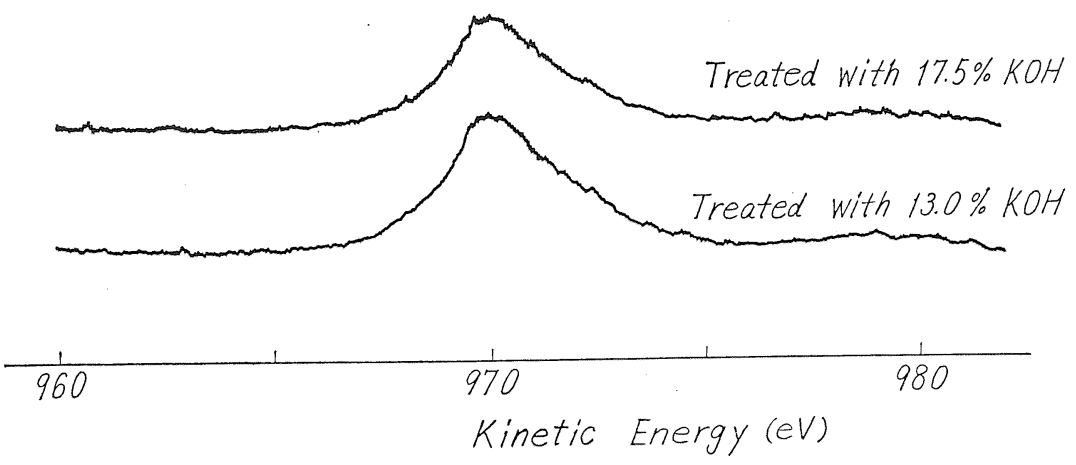

Fig. $8 \mathrm{C}_{1 \mathrm{~S}}$ Spectra of Sheets from Softwood Sulphite Pulp $\left(\mathrm{MgK}_{\alpha}\right)$

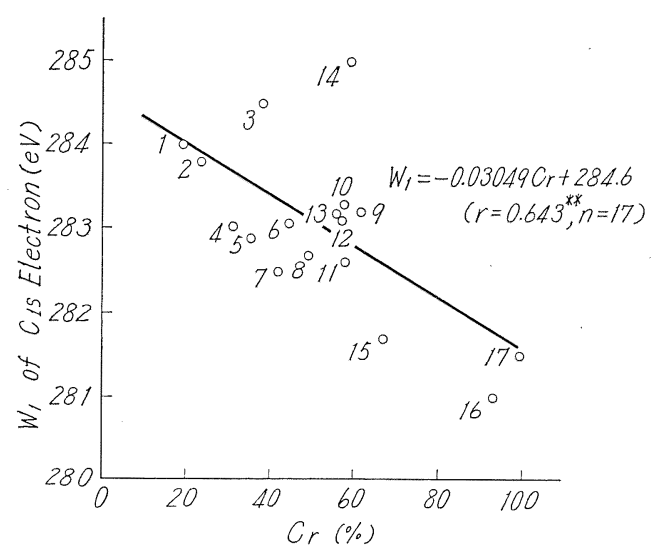

Fig. 9 Ionization Potential $\mathrm{W}_{1}$ of $\mathrm{C}_{1} \mathrm{~s}$ vs. Crystallinity Index $\mathrm{Cr}$ of the Cellulose

1,2: Saponified Acetate

3: Commercialiy Available Cellophane

4: Pure Cellophane

5: NBKP Treated with $17.5 \% \mathrm{KOH}$

6: NBKP Treated with $13.0 \% \mathrm{KOH}$

7: Rayon

8: Avicell

9: NBSP Sheet (CSF 727cc)

10: NBSP Sheet ( $\mathrm{CSF} 572 \mathrm{cc})$

11: NBKP Sheet (CSF 703cc)

12: NBKP Sheet (CSF 417cc)

13: NBKP Sheet (CSF 262cc)

14: Cotton Linter

15: Ramie

16: Valonia Macrophysa

17: Valonia Ventricosa
京農工大学大江礼三郎助教授, 以上の方々に厚く御礼 申し上げます。

(紙パルプ技術協会研究発表会 昭 47.6.23 飞抒いて 発表した）

文 献

1) K. Siegbahn et al; "ESCA, Atomic, Molecular and Solid State Structure Studied by Means of Electron Spectroscopy", Uppsala (1967)

2) M. Born; Atomic Phyics., p. 79, Blackie \& Son limited, London (1953)

3) D. Hercules; Anal. Chem. 42, 1, 20 A(1970)

4) K. Siegbahn; "Alpha-, Beta-and Gammaray spectroscopy.," p. 79 North-Holland Publ Co., Amsterdam (1965)

5) Ibid. p. 845

6) K. Nukasawa, J. Tanaka and S. Nagakura; J. Phys. Soc. Japan., 8, 792 (1953)

7）千原秀昭；現代化学，1，1 (1971)

8) R. A. Pitman and V. W. Tripp; J. Polymer. Sci., PART-A-2, 8, 969 (1970)

9） 和田八三久，高分子., 12，278 (1963) 広瀬英典, 柘植健司, 和田八三久, 応用物理., 30, 417 (1961)

10) M. Norimoto and T. Yamada; Wood Research., No.50 36 (1970)

11）前田浩五郎，星野 清; 日本化学会第 24 年会要 旨集 p. 2040 (1971 年 4 月 大阪)

12）関 集三; 現代化学講座, 水素結合 p. 67 岩波 (1956)

（原稿受付 昭 47.8.19） 